\title{
Management of Independent Campus Curriculum Development from Perspective of Ulul Albab (A Term Addressed to Humans Who Have High Spiritual, Intellectual and Social Strength)
}

\author{
M. Fahim Tharaba ${ }^{1}$, M Mukhibat $^{2}$, Rosida Kerin Meirani ${ }^{3}$ \\ UIN Maulana Malik Ibrahim Malang Jl. Gajayana, no. 50 Malang $^{1,3}$, \\ IAIN Ponorogo Jl. Pramuka, Jalan Pramuka No. 156 Ponorogo $^{2}$ \\ \{fahimtarbiyah@pai.uin-malang.ac.id¹,mukhibat@iainponorogo.ac.id², Anandarose1@gmail.com³
}

\begin{abstract}
Abstrak. The ideals of realizing an independent campus in order to respond to the era of disruption and industrial development 4-0 is a necessity, the global industrial era 4.0 like today, where the influence of technology, especially information, and communication and transportation is so fast, plus the existence of covid 19 is very difficult to find anUlul albab(human beings with high spiritual, intellectual and social strength) profile that is actually used as a standard in the Qur'an, because Ulul albab is not only limited to intellectual abilities, but also must have other abilities that are emotional and spiritual in nature.Management of independent campus curriculum development from ulul$a l b a b$ perspectiveis a model that can be offered to answer it.The model and management implementation of the independent campus curriculum development from the perspective of Ulu al-albab is the aim of this research. The research method used is qualitative approach which in the field of education is often called a naturalistic approach.The results of his research, (1) The management model for the development of the independent campus curriculum from the perspective of Ulu al-albab, namely by the stages of planning, implementation and evaluation by considering elements, philosophy; Moderation; Integration; Ulu al-albab; and Contain theory and application. (2) Implementation of the management of the independent campus curriculum development from the perspective of Ulu al-albab, namely the realization of an independent campus with scientific integration by cultivating a personality with Ulul albab character.
\end{abstract}

Keywords: independent campus; Ulu al-albab; curriculum

\section{Introduction}

Change will continue to run in every line of life, including in the world of education. The duties and responsibilities of education, how the change leads to improvement, is not just maintaining stagnation, or even regression change. According to M. Amien Rais, "change can be classified into three parts, namely: first, conservative, leading to the preservation of old 
established values, even though those values are irrational; secondly, revolutionary radicals, which lead to the uprooting of all values, because the preservation of old values results in social, science and technology stagnation, and so on, so this classification tends to be a chance for sake change, namely changing the origin of change: third, reformist, leading to a combination of conservative and revolutionary radicals, namely changes and shifts in values gradually in accordance with the demands of the Prophet Muhammad. "[1]. Prophet Muhammad message,

"Seek knowledge, from birth, to the grave (death)".

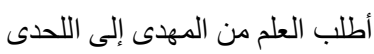

Covid 19 forces us to make changes quickly, like it or not, ready or not, we must adapt quickly and make changes quickly. In the ritual, for example, the priest, before starting the congregation, invites people to close ranks, which is the perfection of prayer ( سووا صففكم فان (2) (التصوية الصففى من تمام الصلاة , the existence of covid 19 makes everything different where there is a social distance, so, how to (ترك المفاسد مقدم على الجلب المصالح) "prioritize preventing evil from attracting benefits", is totally different., and so on. Then how can religion and education respond to things like that phenomenon, so that it is still in accordance with the concept of الإسلام صالح فى كل زمن و مكان

"Islam is in accordance with its locus and tempus". How Islam embodies its main values, eternal (not limited by time), universal (not limited by space), and cosmopolitan (not limited by space).

On the other hand, education has the duty to maximize its educational duties, one of which is through educational institutions. "As an educational institution, the campus has a role as an institution that is responsible for capturing the existing changes, and at the same time as a cultural heritage for values relevant to the existing changes"[2]. That is what underlies the importance of the campus position as an agent of change, as well as an agent of conservation.

Furthermore, the campus also functions as a place for knowledge transfer, value transfer, and also functions to maintain and develop noble traditions and cultures in a society through the process of forming personality (in the making personality processes) so that they become human adults who are able to stand alone in the culture and society around them [3].

The study of ulual-albab, Al-Qur'an itself places them (ulual-alba (human beings with high spiritual, intellectual and social strength)) in a special position, namely people who are able to think about things that are not able to be done by a group of people in general. In the industrial era 4.0 or the era of global disruption like today, where the influence of technology, especially information, and communication and transportation is so fast, plus the existence of Covid 19, it is very difficult to find the Ulul albab profile that is really used as a benchmark in the Qur'an , because Ulul albab is not limited to intellectual abilities alone, but also must have other abilities that are emotional and spiritual [4].

The Ulul albab discourse will always be related to the integration of science and Islam, as well as the moderation of religion. It must be understood that "Religion" and "Science" are integral entities that cannot be separated from each other, so that any discourse on methodology requires philosophical touches."Without a sense of philosophy, a methodology will lose its substance". Therefore, it is necessary to have an epistemological vision that can describe integrally and integratedly towards the three main currents in Islamic teachings, namely: aqidah, syari'ah and morality. "The tendency to impose moral values dogmatically into scientific argumentation will only push science backwards to the Pre-Copernican era and invite the possibility of a Galileo inquiry (1564-1642 AD) in modern times. Likewise, the 
tendency to ignore moral values in the development of science and technology will also lead to dishumanism. This is what underlies the need for a science integralism paradigm [5].

Minister of National Education Nadiem Makarim (in accordance with Permendikbud (regulations of the minister of education and culture) Number 3 of 2020) aspires to create an independent campus in order to respond to the era of disruption and industrial development 40 . Therefore, how the campus curriculum management in the Ulul albab perspective in responding to the various background phenomena above is very urgent to do in order to provide orientation and guidelines that can be used in the development of Islamic sciences in an integrated and interconnected manner.

\section{Research Method}

This research uses a qualitative approach [6], [7], or" in education it is often called a naturalistic approach "[8]. In this study, the research steps were carried out as follows. First, "data was collected, namely on the research site (State Islamic University (UIN) Maulana Malik Ibrahim Malang) as the subject". Second, "based on the conceptual findings of the subject, then an analysis is carried out by carrying out the conceptual development resulting from the subject". To reveal this latest finding, a modified analytic induction method was used as a way to develop and test a theory [6].

In order to obtain data in an integrated holistic manner, and pay attention to the relevance of data based on focus and objectives, three techniques were used to collect data in this study, namely: " (1) in-depth interview; (2) participant observation; and (3) study of document". "Almost all qualitative research authors agree that these three techniques are the basic techniques used in qualitative research"[6].

\section{Research Results and Discussion}

\subsection{Management Model of the Independent Campus Curriculum Development in Ulu al- albab Perspective}

Curriculum development management is an activity designed to develop a curriculum in an educational system as a whole. According to Fahim, curriculum development management is always related to policies, programs and activities [9, p. 27]. There are many approaches in curriculum development management, including (1) Academic Subject Approach, (2) Humanistic Approach, (3) Technological Approach, and (4) Social Reconstruction Approach.[9, p. 79]. Curriculum development management problems are seen as a professional act. This means that "in an effort to develop a curriculum a managerial skill is needed in the sense of the ability to plan, organize, manage and control the curriculum".[10] The first two abilities are abilities in "Curricullum planning". And two other capabilities are referred to as capabilities in terms of "Currikullum implementation". All these abilities are defined as curriculum development management skills.

There are at least two main problems in curriculum development management, namely: 1) How is the management in curricular planning? 2) How is the management in currikulum implementation?

The first problem, "management in curriculum planning. Starting from several thoughts, about who really is in curriculum planning, what factors drive a curriculum to be changed. The 
second problem, "there are several factors that influence curriculum implementation, (1) with regard to the approach to planning, (2) with regard to the implementation strategy, especially the problem of activist support in the form of supervisor assistance to teachers".

How is the management of curriculum development in the context of independent campus? The independent campus policy is expected to accelerate innovation. Innovation, which is the main goal of higher education, cannot be separated from the development of curriculum management. The independent campus is here to eliminate the paradigm that education is only the responsibility of the education unit. According to Nadiem, "with the independent campus policy, the responsibility for education can be shared by industry, associations and elements of society". Finally, it is hoped that the independent campus can train students to be more adaptive. "The independent campus policy, namely the exemption of students from studying outside the study program, will make students more adaptive in dealing with post-college situations and an ever-developing era" [11].

The management model for the development of the independent campus curriculum from the perspective of Ulu al-albab, namely by planning, implementation and evaluation stages by considering elements, (1) philosophy, (2) moderation, (3) integration, (4) Ulu al-albab, (5) Housing theory and application.

\subsection{Management of Independent Campus Curriculum Development by Fostering a Person with Ulul albab Character}

Ulul albab in language comes from two words: "ulu and al-albab". "Ulu" means "who has", while "al albab" has various meanings. The word "Ulul albab" appears 16 times in the Quran ". In the Indonesian translation, the meaning most often used is "reason". Therefore, "Ulul albab is often defined as "who has reason"or "people who understand". Al-albab is the plural form and comes from word "al-lubb". This plural form indicates that the Ulul albab is a person who has a multi-layered brain, aka a sharp brain. A search of the English translation finds a wider variety of meanings. "Ulul albab has several meanings, which are linked to mind, feeling (heart), intellect, insight, understanding, wisdom".

The reading of various interpretations of the verses containing the word "Ulul albab" leads to a big conclusion: "Ulul albab decorates his time with two main activities, namely thinking and remembrance. These two activities go hand in hand ". Ulul albab remembering Allah, in any situation: in a standing position, sitting, or lying down (Ali Imran 3: 191), fulfilling a promise (Ar-Ra'd 13:20), connecting those who need to be connected and fear with bad reckoning (Ar-Ra'd 13:21), patience and expect the pleasure of Allah, perform prayers, pay infaq and reject evil with good (Ar-Ra'd 13:22) ". Here, "remembrance is done by building transcendental vertical relationships (such as establishing prayers) and social horizontal relationships (such as paying infaq (removing part of the assets or income for an interest ordered in Islamic teachings) and connecting brotherhood)".

In thinking, Ulul albab involves a variety of objects: "natural phenomena, such as the change of night and day and the creation of the heavens and the earth (Ali Imran 3: 190-191) and the cycle of plant life that grows due to rain and eventually dies (Az-Zumar 39: 21), social phenomena, such as history or past stories (Yusuf 12:111)".

As a concept, Ulul albab needs to be operationalized or grounded. The following strategies were envisioned after carrying out tadabbur on the various verses above, namely: "(a) increasing integration, (b) sharpening sensitivity, (c) ensuring relevance, (d) developing imagination, and (e) maintaining independence". 
Improving integration. "Ulul albab maintains the integration between thinking and remembrance, between science and faith". The integration of the aspects of dhikr (remembrance) and thought of Ulul albab is strived to be implemented into three levels of Islamization: (a) "Self-Islamization, which is aimed at becoming a pious human being, including being socially virtuous"; (b) "Islamization of institutions, by injecting value into decision-making and business process design"; and (c) "Islamization of science, which is now more commonly referred to as the integration of science with Islamic values".

Sharpening sensitivity. "Thinking requires sensitivity (Yusuf 12: 105-106)". "The same phenomenon can provide various meanings if approached with different levels of sensitivity. Sensitivity can be honed by looping, which goes hand in hand with the Q.S. al-Alaq verses 15 , that critical reading is repeated (in verses 1 and 3 ). This recitation is still accompanied by remembrance: based on the "name of Allah" (verse 1) and still glorifying Allah (verse 3) ".

Ensuring relevance. "The thought process must produce benefits. Here, the issue of relevance becomes important. It could be that the human ability to think has not been able to open the veil and understand it well, aka functional thinking. But for Ulul albab, everything is returned to the belief that Allah created everything with a purpose, not in vain (Ali Imran 3: 192)".

Developing imagination. "The combination of thought and dhikr (remembering Allah) activities should produce a more advanced imagination of the people and Muslims (Surah AlHashr 59:18; An-Nisa 4: 9). In order to move and progress, we need to have an imagination of the future and not get caught up in reactive attitudes that consume energy. Therefore, Ulul albab must put forth a critical, creative mind. The critical characteristic of the character of dhikr appears when dealing with concrete problems. Dzkir (remembrance) means remembering or getting a warning. Therefore, the character of those who make dhikr is a reminder.

Maintain independence. "Ulul albab should also be accustomed to thinking independently. Not based on current interests and current context. The basis of thinking is perennial or eternal values. This independence becomes very important in the post-truth era when emotions are more prominent than common sense. (Summarized from the presentation at the October 30 2018 Seminar.)

There are two most basic things that can be categorized as Ulul albab, namely "dhikr and fikir" (remembrance and thought). "Remembrance includes thought or thought, it is contained in the meaning of dhikr as in dhikr it contains elements of thought. On the other hand, there is also dhikr in thought. The word "fakkara" is often interpreted as "to reflect" or "reflection". In Indonesian this expression contains elements of the meaning of "contemplating".It can be understood that "those who contemplate or think about all of Allah's creations are also dhikr". For more details about the characteristics of Ulul albab as expressed sixteen times in the Qur'an, it can be formulated as follows: a. "Having a pure and clear mind and a sharp eye in catching the phenomena at hand, using the heart for remembrance of Allah and utilizing the mind to reveal the secrets of the universe, actively demanding knowledge (Ali Imran [3]: 7) by contemplating Allah's creation in the sky and on the earth and paying attention to all of his creations that were made from water as a source of conducting studies and research for the benefit of life.

To develop Ulul albab as stated earlier, there are several things we can do to make it happen, namely, "First, Muslims must be able to take advantage of increasingly affordable technological means to the countryside as a means of struggle (jihad). Second, Muslims must continuously improve human resources (HR) with quality science and technology and also faith and piety simultaneously, or improve themselves towards spiritual, moral and intellectual 
strength. Third, the modernization process is something that is necessary for reforming the Islamic education system, starting from the paradigm, concept, framework, and evaluation". [12]

Implementation of the management of the independent campus curriculum development from the perspective of Ulu al-albab, namely the realization of an independent campus with scientific integration by fostering a personality with Ulul albab character, who is not limited to only intellectual abilities, but also must have other abilities that are emotional and spiritual, which can describe integrally and integratedly with the three main currents in Islamic teachings, namely:aqidah (trust), shari'ah (a Muslim way of life that contains the decrees of Allah and the provisions of His Messenger, both in the form of prohibitions and in the form of orders, covering all aspects of life and human life) and morality, by functioning the campus as a place for knowledge transfer, value transfer, also functions to maintain and develop noble traditions and cultures in a society through the process of forming personality (in the making personality) processes) so that they become mature humans who are able to stand alone in the culture and society around them, equipped with religious moderation as a basis for thinking, behaving and as a formulation of policies to act in society.

\section{Conclusion}

The management model for the development of the independent campus curriculum from the perspective of Ulu al-albab, namely by planning, implementation and evaluation stages by considering elements, (1) philosophy, (2) moderation, (3) integration, (4) Ulu al-albab, (5) Housing theory and application.Implementation of the management of the independent campus curriculum development from the perspective of Ulu al-albab, namely the realization of an independent campus with scientific integration by fostering a personality with Ulul albab character, who is not limited to only intellectual abilities, but also must have other abilities that are emotional and spiritual, which can describe integrally and integratedly with the three main currents in Islamic teachings,namely:aqidah (trust), shari'ah (a Muslim way of life that contains the decrees of Allah and the provisions of His Messenger, both in the form of prohibitions and in the form of orders, covering all aspects of life and human life) and morality, by functioning the campus as a place for knowledge transfer, value transfer, also functions to maintain and develop noble traditions and cultures in a society through the process of forming personality (in the making personality) processes) so that they become mature humans who are able to stand alone in the culture and society around them, equipped with religious moderation as a basis for thinking, behaving and as a formulation of policies to act in society.

\section{References}

[1] A. Mujib and J. Mudzakir, Ilmu Pendidikan Islam. Jakarta: Kencana, 2006.

[2] M. F. Tharaba, "Kampus Islam sebagai Agent of Change," Ulul Albab Jurnal Studi Islam, vol. 12, no. 1, pp. 67-79, 2011.

[3] M. F. Tharaba, Kepemimpinan Pendidikan Islam (Islamic Educational Leadership). Malang: Dreamlenterabuana, 2016.

[4] A. Herawati, "Kontekstualisasi Konsep Ulul Albab Di Era Sekarang," Fikrah, vol. 3, no. 1, pp. 123-140, 2015. 
[5] M. Zainuddin, "Menuju Integrasi Ilmu Dan Agama," Gema, Nov. 12, 2013.

[6] C. R. Bogden and S. K. Biklen, Qualitative Research for Education: An Introduction to Theory and Methods, Boston: Ally and Bacon. London: Ally and Bacon, Inc, 1982.

[7] N. K. Denzin and Y. S. Lincoln, Handbook of Qualitative Research. SAGE Publications, 1994.

[8] E. G. Guba and Y. S. Lincoln, Effective Evaluation. Books on Demand, 1981.

[9] M. F. Tharaba, Pengembangan Kurikulum PAI. Malang: Dreamlenterabuana, 2017.

[10]"The Islamic Education Reform Early 20th Century | Tharaba | Al-Tahrir: Jurnal Pemikiran Islam.” http://jurnal.iainponorogo.ac.id/index.php/tahrir/article/view/2008 (accessed Oct. 06, 2020).

[11] W. A. Prodjo, “4 Alasan Nadiem Makarim Mengeluarkan Kebijakan Kampus Merdeka Halaman all,” KOMPAS.com, Jan. 2020. https:/edukasi.kompas.com/read/2020/01/25/20283891/4-alasan-nadiem-makarimmengeluarkan-kebijakan-kampus-merdeka (accessed Oct. 05, 2020).

[12] I. Munandar, "Integrasi Dalam Study Islam." 